\title{
ADDITIONS TO THE CHECK-LIST OF BIRDS OF THE MOUNTAIN ZEBRA NATIONAL PARK
}

\author{
B. L. PENZHORN and P. J. L. BRONKHORST \\ Mountain Zebra National Park \\ Private Bag X66 \\ Cradock \\ 5880
}

Abstract - Twenty-two additional bird species have been recorded in the Park, increasing the check-list total to 170 species.

In his report on the bird-life in the Mountain Zebra National Park, Skead (1965) reported 148 bird species in the Park. He predicted that vagrants could increase the total to $190-200$ species. Since the publication of Skead's check-list, several bird-watchers have visited the Park and compiled lists of the birds seen. The authors have also kept a look-out for species not previously reported. Twenty-two additional species have been recorded, increasing the number of species recorded in the Park to 170.

The 22 additional species are listed below. The numbers denote those used by McLachlan and Liversidge (1957) in Roberts birds of South Africa and the nomenclature follows the Check list of the birds of South Africa (S.A.O.S. List Committee 1969).

47 WHITE-BREASTED CORMORANT WITBORSDUIKER

Phalacrocorax lucidus

White-breasted cormorants are recorded regularly at the large dam near the museum.

50 REED CORMORANT RIETDUIKER

Phalacrocorax africanus (Gmelin)

A few vagrants have been recorded occasionally at the large dam near the museum.

61 CATTLE EGRET

Ardeola ibis (Linnaeus) BOSLUISVOËL

Cattle egrets are recorded regularly, although not resident in the Park. Skead (1965) predicted that vagrants from the lucerne lands in the Great Fish River Valley would visit the Park.

79 BLACK STORK GROOT SWARTSPRINKAANVOËL Ciconia nigra (Linnaeus) Black storks have been recorded infrequently during the summer months. 
LEPELAAR

Spoonbills are observed occasionally at dams in the Park. On one occasion six were seen together at the large dam near the museum.

95 BLACK DUCK

Anas sparsa Eyton SWARTEEND

Black duck are seen on the Wilgerboom River, usually where there is some cover, but a pair has been observed on a few occasions in an open valley at the upper reaches of the River. A black duck was flushed off a nest containing seven eggs on 1975.09.19. The nest was situated on a ledge on a cliff-face, about six metres above the level of the River.

114 LANNER FALCON

Falco biarmicus Temminck

EDELVALK

The presence of this species, predicted by Skead (1965), can now be confirmed. It appears to be rare in the Park.

122 GREATER KESTREL GROOT ROOIVALK

Falco rupicoloides A. Smith

Members of the Eastern Cape Wild Bird Society observed six greater kestrels near the look-out point in the Park in March 1969 (Brown 1969a).

134 TAWNY EAGLE

Aquila rapax (Temminck) KOUVOËL

A single bird was seen on the Rooiplaat Plateau on three consecutive days during December 1973 (B.L.P.). This species was regarded by Skead (1967) as rather a vagrant of irregular appearance anywhere throughout the Eastern Cape.

158 LITTLE SPARROWHAWK

Accipiter minullus (Daudin) KLEIN SPERWER

A single bird was observed once in the dense riverine scrub in March 1973 (B.L.P.). In the Eastern Cape this species usually occurs in the forests of the coastal and sub-coastal belt (Skead 1967).

210 MOORHEN

WATERHOENDER

Gallinula chloropus (Linnaeus)

A single moorhen was seen on a few consecutive days in September 1975 below the museum at the drift in the Wilgerboom River.

245 BLACKSMITH PLOVER Vanellus armatus (Burchell) BONTKIEWIET

Blacksmith plovers have been recorded infrequently, mainly at the small dam near the Nature Conservator's house. 

GEWONE RUITER

Single birds have been seen on sandbanks along the Wilgerboom River.

367 CAPE EAGLE-OWL

Bubo capensis A. Smith KAAPSE OORUIL

An injured owl found in the Park was identified as a Cape eagleowl by P. J. L. B.

368 SPOTTED EAGLE-OWL Bubo africanus (Temminck) GEVLEKTE OORUIL

These owls are occasionally seen at dusk and at night.

373 FIERY-NECKED NIGHTJAR SUID-AFRIKAANSE NAGUIL

Caprimulgus pectoralis Cuvier

On moonlit nights, these nightjars are infrequently heard calling. Recorded at Berghof, Babylons Toren, the museum and in Fonteinkloof.

397 MALACHITE KINGFISHER Alcedo cristata Pallas KUIFKOPVISVANGER

Recorded once at a small dam in March 1971 and along the Wilgerboom River in September 1975.

485 GREY-BACKED FINCH-LARK Eremopterix verticalis (A. Smith) GRYS KAFFERTJIE

Recorded infrequently on the Rooiplaat Plateau.

\section{FORK-TAILED DRONGO}

Dicrurus adsimilis (Bechstein) MIKSTERTBYVANGER

Recorded regularly in the dense Acacia karroo scrub in the valley near the Nature Conservator's house and in the tall exotic trees at the house itself.

ENGELSE MOSSIE

House sparrows were first recorded in the Park in June 1968 by Penzhorn and Morris (1968). They must have arrived after 1964, when Skead (1965) concluded his survey of the bird-life in the Park. House sparrows are resident at Babylons Toren, Berghof, Weltevrede and the museum.

808 RED BISHOP-BIRD

Euplectes orix Linnaeus

ROOI KAFFERVINK

Red bishop-birds have been recorded by P. J. L. B. 


\section{GEELOOGSYSIE}

Brown (1969b) recorded a small flock of these canaries in the Park in March 1969.

The following eight species have also been reported, but require confirmation:

146 Black-breasted snake-eagle Circaetus pectoralis A. Smith

160 African goshawk Accipiter tachiro (Daudin)

371 European nightjar Caprimulgus europaeus Linnaeus

395 Giant kingfisher Ceryle maxima (Pallas)

458 Rufous-naped lark Mirafra africana A. Smith

519 Golden oriole Oriolus oriolus (Linnaeus)

540 Rock-jumper Chaetops frenatus (Temminck)

649 Tawny-flanked prinia Prinia subflava (Gmelin).

\section{Acknowledgements}

Thanks are due to Mr C. J. Skead for reading and commenting on the manuscript.

\section{REFERENCES}

BROWN, D. M. V. 1969a. New distributional data: 2. Greater kestrel. Ostrich 40:131.

BROWN, D. M. V. 1969b. New distributional data: 2. Yellow-eye canary. Ostrich 40:132.

McLACHLAN, G. R. and R. LIVERSIDGE. 1957. Roberts birds of South Africa. 2nd ed. Cape Town: Trustees of the S.A. Bird Book Fund.

PENZHORN, B. L. and A. K. MORRIS. 1968. New distributional data: 1. House sparrow. Ostrich 39:272.

S.A.O.S. LIST COMMITTEE. 1969. Check list of the birds of South Africa. Cape Town: South African Ornithological Society.

SKEAD, C. J. 1965. Report on the bird-life in the Mountain Zebra National Park, Cradock, C.P. 1962-1964. Koedoe 8:1-40.

SKEAD, C. J. 1967. Ecology of birds in the Eastern Cape Province. Ostrich Suppl. 7:1-103. 